\title{
KANDUNGAN LOGAM BERAT PADA BEBERAPA LOKASI PERAIRAN INDONESIAPADA TAHUN 2001 SAMPAI DENGAN 2005
}

\author{
Tuti Hartati Siregar dan Jovita Tri Murtini*)
}

\begin{abstract}
ABSTRAK
Logam berat merupakan salah satu bahan pencemar yang perlu diwaspadai. Di Indonesia, pencemaran logam berat dapat berasal dari limbah industri, pertanian maupun rumah tangga. Oleh karena itu, Balai Besar Riset Pengolahan Produk dan Bioteknologi Kelautan dan Perikanan telah melakukan penelitian monitoring residu logam berat pada biota maupun perairan di beberapa lokasi selama 5 tahun yaitu dari tahun 2001 sampai dengan 2005. Tulisan ini merupakan review dari hasil penelitian tersebut. Pada tahun 2001, Perairan Dadap, Cilincing, Demak, dan Pasuruan telah tercemar oleh logam Hg, sementara Perairan Tanjung Pasir dan Blanakan belum tercemar dengan residu $\mathrm{Hg}$ di bawah 2 ppb. Pada tahun 2002, perairan laut di Sumatera yang diwakili oleh Perairan Mentok, Perairan Tanjung Balai, Perairan Tanjung Jabung Timur, dan Perairan Bagan Siapi-api terbukti masih aman untuk kebutuhan perikanan dengan residu $\mathrm{Hg}$ kurang dari $2 \mathrm{ppb}$. Kerang yang hidup di perairan tersebut juga masih aman untuk dikonsumsi. Ambang batas residu logam dalam produk perikanan adalah $\mathrm{Hg} 500$ ppb, Cd 1.000 ppb, Pb 2.000 ppb, dan $\mathrm{Cu}$ 20.000 ppb. Pada tahun 2002, perairan Sidoarjo juga masih dalam batas aman dengan residu $\mathrm{Hg}$ kurang dari $2 \mathrm{ppb}$, tetapi Perairan Pasuruan telah tercemar oleh logam $\mathrm{Hg}$ dengan residu $\mathrm{Hg}$ di atas 2 ppb. Pada tahun 2002, kerang yang hidup di perairan Jawa dan Bali masih aman untuk dikonsumsi. Pada tahun 2003, perairan di Kalimantan dan Sulawesi masih dalam batas aman, begitu juga dengan biota yang hidup di perairan tersebut masih aman untuk dikonsumsi. Pada tahun 2005, Muara Sungai Kahayan dan Muara Sungai Barito telah tercemar oleh logam Cd dan $\mathrm{Cu}$, tetapi ikan yang hidup di dalamnya masih aman untuk dikonsumsi. Pada tahun tersebut Waduk Saguling telah tercemar oleh logam $\mathrm{Pb}, \mathrm{Cd}$, dan $\mathrm{Cu}$ sementara Waduk Cirata tercemar oleh logam $\mathrm{Hg}$ dan Waduk Jatiluhur tercemar oleh logam $\mathrm{Cu}$ dan $\mathrm{Cd}$. Ikan yang hidup di ketiga waduk tersebut masih aman untuk dikonsumsi.
\end{abstract}

KATA KUNCI: logam berat, perairan, sedimen, biota

\section{PENDAHULUAN}

Pencemaran pada perairan yang diakibatkan oleh logam berat telah lama diteliti. Pada tahun 1956, diberitakan bahwa residu metil merkuri dari limbah pabrik kimia yang dibuang langsung ke teluk Minamata Jepang, menyebabkan ratusan jiwa meninggal akibat makan ikan yang tercemar oleh bahan berbahaya tersebut (Anon., 2005). Di Indonesia, masalah pencemaran logam berat tidak hanya berasal dari industri, tetapi juga dapat berasal dari limbah pertanian dan rumah tangga. Kesadaran masyarakat akan bahaya pencemaran masih sangat kurang. Sebagian bahan kimia tersebut bersifat toksik dan dapat berdampak pada pencemaran lingkungan yang sangat besar (Murtini et al., 2003c). Menurut Rahmansyah (1997), penurunan kualitas lingkungan hidup perikanan berdampak pada penurunan produktivitas dan higienitas komoditas perikanan yang dihasilkan. Dalam dunia perdagangan, produk pangan yang telah tercemar akan berdampak buruk pada konsumen sehingga nilainya di pasaran akan turun. Menurut Irianto \& Poernomo (2000), penyebab tidak amannya suatu produk untuk dikonsumsi adalah akibat adanya senyawa atau bahan kimia, mikroorganisme, dan cemaran fisik berbahaya yang tidak dikehendaki keberadaannya atau jumlahnya melebihi ketentuan yang telah ditetapkan. Keamanan produk ini perlu diperhatikan untuk menjaga kepercayaan konsumen dalam dan luar negeri terhadap produk yang dihasilkan Indonesia (Murtini et al., 2003b). Dalam bidang ekspor produk perikanan, Indonesia menempati urutan nomor dua dari sebelas negara pengekspor dalam hal jumlah penolakan dari Food and Drug Administration (FDA) selama empat bulan dari Mei sampai dengan Agustus 1998. Alasan penolakan tersebut menurut Raharjo (1999) adalah adanya cemaran bakteri Salmonella, kotoran, benda asing, dan zat beracun pada produk perikanan ekspor.

Logam berat terutama metil merkuri adalah bahan pencemar yang perlu diwaspadai. Logam-logam berat yang terlarut dalam perairan pada konsentrasi tertentu akan berubah fungsi menjadi racun bagi kehidupan perairan (Murtini et al., 2001). Menurut FDA dalam Anon (1998), selain merkuri $(\mathrm{Hg})$, jenis logam berat yang merupakan unsur membahayakan kesehatan

\footnotetext{
*) Peneliti pada Balai Besar Riset Pengolahan Produk dan Bioteknologi Kelautan dan Perikanan
} 
antara lain timbal $(\mathrm{Pb})$, kadmium (Cd), arsen (As), tembaga $(\mathrm{Cu})$, kromium $(\mathrm{Cr})$, dan nikel (Ni). Urutan tingkat toksisitas logam berat tersebut berturut-turut adalah $\mathrm{Hg}, \mathrm{Cd}, \mathrm{Pb}, \mathrm{As}, \mathrm{Cu}$, dan Zn (Anon, 1985 dalam Fajri, 2001). Logam-logam berat seperti $\mathrm{Hg}, \mathrm{Pb}, \mathrm{Cd}$, dan $\mathrm{Pb}$ berbahaya karena bersifat biomagnifikasi, yaitu dapat terakumulasi dan tinggal di jaringan tubuh organisme dalam jangka waktu lama sebagai racun terakumulasi. Logam-logam yang dapat menyebabkan keracunan biasanya terikat dengan protein sebagai metalotionin (Darmono, 1995 dalam Murtini et al., 2003a). Dampak keracunan yang disebabkan oleh merkuri adalah terjadinya kerusakan syaraf, paralisis, kebutaan, dan keterbelakangan mental pada bayi. Keracunan kadmium menyebabkan tekanan darah tinggi, kerusakan ginjal, kehilangan sel darah merah, gangguan lambung, dan kerapuhan tulang (Mulyono, 2000). Daya racun timbal dan tembaga lebih rendah dibanding merkuri dan kadmium tetapi memiliki sifat kronis dan kumulatif (Mulyono, 2000; Anon, 2006).

Pengukuran pencemaran logam berat dilakukan pada perairan, selain itu juga dapat dilakukan pada biota yang ada di perairan tersebut. Pengukuran residu logam berat pada biota perairan bisa menjadi bioindikator dampak logam berat pada kesehatan organisme dan lingkungannya (Krishnakumar et al., 1994 dalam Acker et al., 2005). Jenis biota laut yang sangat potensial tercemar logam berat adalah kekerangan, mengingat cara makannya dengan menyaring air (Murtini \& Ariyani, 2005b). Kekerangan juga mengandung senyawa karotenoid yang tinggi sehingga menyebabkan biota tersebut sangat resisten terhadap polusi yang terjadi di lingkungan perairan tempat tinggalnya (Tewari et al., 2001). Di samping itu, sifat kekerangan ini lebih banyak menetap (sessile) dan bukan termasuk migratory (Wahyuni \& Hartati, 1991). Menurut Tewari et al. (2001) akumulasi konsentrasi logam pada kekerangan tergantung pada ukuran, jenis kelamin, habitat makanan, kondisi reproduksi, musim, dan tingkat polusi.

Logam-logam berat yang terdapat dalam biota perairan umumnya tidak akan dikeluarkan lagi sehingga akan terakumulasi dalam tubuh biota tersebut. Sistem rantai makanan menunjukkan bahwa manusia merupakan pengakumulasi logam berat paling tinggi karena berperan sebagai pemangsa tingkat tinggi (Hutabarat et al., 1985 dalam Murtini et al., 2003b). Akibat dari pencemaran tidak secara langsung dirasakan oleh manusia karena bahan pencemar tersebut bersifat akumulatif yang akan berdampak kronis dalam tubuh (Yennie \& Murtini, 2005).

\section{KONDISI PERAIRAN DI INDONESIA 2001-2005}

\section{a) Kondisi Perairan di Pulau Sumatera}

Kadar merkuri air laut di pantai timur Sumatera yang diwakili oleh Perairan Bagan Siapi-api (Riau), Tanjung Balai (Sumatera Utara), Mentok (Bangka), dan Tanjung Jabung Timur (Jambi) masih dibawah ambang batas aman untuk perikanan (Gambar 1).

Perairan Tanjung Balai sudah harus mendapat perhatian karena kandungan merkurinya sebesar 1,86 ppb telah mendekati ambang batas aman untuk perikanan yaitu $2 \mathrm{ppb}$ (Murtini et al., 2002). Menurut Murtini et al. (2003b) kandungan merkuri di Perairan Bagan Siapi-api dan Tanjung Jabung Timur pada jarak 1 mil lebih tinggi dibandingkan pada jarak 2 mil karena adanya aliran sungai Rokan yang membawa bahanbahan hasil buangan hasil industri di daerah aliran sungai. Merkuri yang terdapat pada sedimen secara umum lebih tinggi dibanding yang terdapat dalam air. Hal ini kemungkinan disebabkan oleh proses

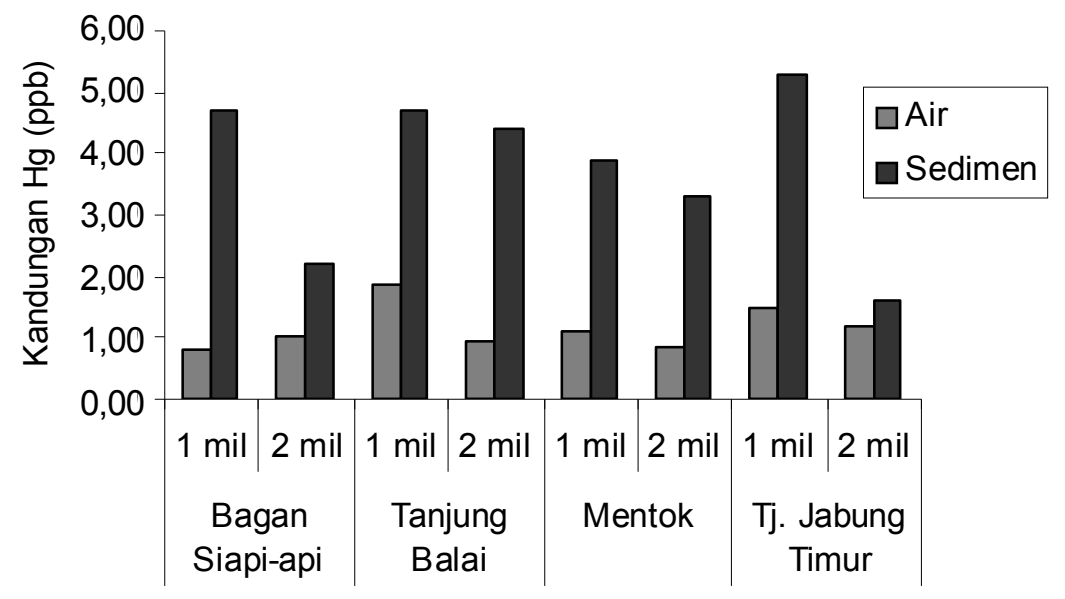

Gambar 1. Kandungan merkuri air laut dan sedimen di Perairan Pantai Timur Sumatera pada tahun 2002. 
pengendapan suspensi senyawaan merkuri yang tercampur dengan lumpur kemudian terakumulasi (Rochyatun, 1997).

Kandungan logam berat pada kerang darah di Peraian Bagan Siapi-api, Tanjung Balai, Tanjung Jabung Timur, dan Mentok dapat dilihat pada Tabel 1. Kerang darah yang terdapat di perairan Pantai Timur Sumatera masih aman untuk dikonsumsi. Ambang batas logam $\mathrm{Hg}, \mathrm{Cd}, \mathrm{Pb}$, dan $\mathrm{Cu}$ yang diperbolehkan dalam produk perikanan berturut-turut adalah $500 \mathrm{ppb}$, 1000 ppb, 2000 ppb, dan 20000 ppb (Anon., 1989). serius karena akan mempengaruhi kualitas produk perikanan di daerah tersebut (Anon., 2007). Produk perikanan Indonesia, terutama untuk produk-produk perikanan jenis Scrombidae, mengandung logam berat yang cukup tinggi sehingga ditolak di pasar internasional.

Kandungan logam berat $\mathrm{Hg}, \mathrm{Cd}, \mathrm{Pb}$, dan $\mathrm{Cu}$ pada kerang darah di Perairan Jawa dapat dilihat pada Tabel 2. Terlihat bahwa kandungan $\mathrm{Pb}$ dalam daging kerang lebih tinggi dibanding logam lain. Hal ini kemungkinan disebabkan turunnya hujan yang membawa $\mathrm{Pb}$ dari

Tabel 1. Kandungan logam berat kerang darah di Perairan Bagan Siapi-api, Tanjung Balai, Tanjung Jabung Timur, dan Mentok tahun 2002

\begin{tabular}{|c|c|c|c|c|c|}
\hline \multirow{2}{*}{ Lokasi } & \multirow{2}{*}{ Bulan } & \multicolumn{4}{|c|}{ Kadar logam (ppb) } \\
\hline & & $\mathrm{Hg}$ & Cd & $\mathbf{P b}$ & $\mathrm{Cu}$ \\
\hline \multirow[t]{3}{*}{ Bagan Siapiapi } & April & 1,77 & 11,70 & 0,07 & 8,77 \\
\hline & Juni & 0,16 & 22,36 & 0,03 & 8,08 \\
\hline & Agustus & 0,17 & 0,05 & 0,22 & 0,04 \\
\hline \multirow[t]{3}{*}{ Tanjung Balai } & April & 1,44 & 16,81 & 0,07 & 8,94 \\
\hline & Juni & 0,25 & 23,21 & 0,03 & 7,94 \\
\hline & Agustus & 2,02 & 0,07 & 0,19 & 0,04 \\
\hline \multirow[t]{3}{*}{ Tanjung Jabung Timur } & Mei & 0,74 & 16,81 & 0,05 & 7,93 \\
\hline & Juli & 0,21 & 22,00 & 0,03 & 23,23 \\
\hline & Oktober & 0,24 & 0,11 & 0,23 & 0,05 \\
\hline \multirow[t]{3}{*}{ Mentok } & Mei & 0,35 & 11,88 & 0,06 & 9,09 \\
\hline & Juli & 0,15 & 25,11 & 0,05 & 8,37 \\
\hline & Oktober & 0,05 & 0,01 & 0,27 & 0,02 \\
\hline
\end{tabular}

\section{b) Kondisi Perairan di Pulau Jawa}

Kandungan merkuri dalam air laut dan sedimen di Perairan Jawa yang diwakili oleh Perairan Tanjung Pasir, Dadap, Cilincing, Blanakan, Brebes, Demak, Sidoarjo, dan Pasuruan dapat dilihat pada Gambar 2. Kandungan Hg di Perairan Tanjung Pasir, Dadap, Blanakan, Brebes, dan Sidoarjo masih aman untuk perikanan. Kandungan merkuri di perairan tersebut masih berada di bawah ambang batas aman yaitu 2 ppb, sedangkan perairan Cilincing, Demak, dan Pasuruan sudah tercemar oleh merkuri (Murtini \& Ariyani, 2005b; Murtini et al., 2003c). Terlihat dari Gambar 2 bahwa kandungan Hg pada ketiga perairan tersebut telah melewati ambang batas aman untuk perikanan. Hal ini harus mendapat perhatian yang buangan gas bahan bakar kendaraan bermotor dan buangan limbah industri dan tanah yang mengandung $\mathrm{Pb}$ (Ewers \& Schlipkoter, 1991 dalam Murtini \& Ariyani, 2005).

Kerang darah (Anadara granosa) yang hidup di Perairan Jawa masih aman untuk dikonsumsi. Kandungan logam berat $\mathrm{Hg}, \mathrm{Cd}, \mathrm{Pb}$, dan Cu masih berada di bawah ambang batas aman.

\section{c ) Kondisi Perairan di Kalimantan dan Sulawesi}

Perairan di daerah Kalimantan dan Sulawesi Selatan meliputi Banjarmasin, Pontianak, Balikpapan, dan Makassar yang diteliti pada bulan Juni, Agustus, dan Oktober tahun 2003 secara umum telah tercemar merkuri. 


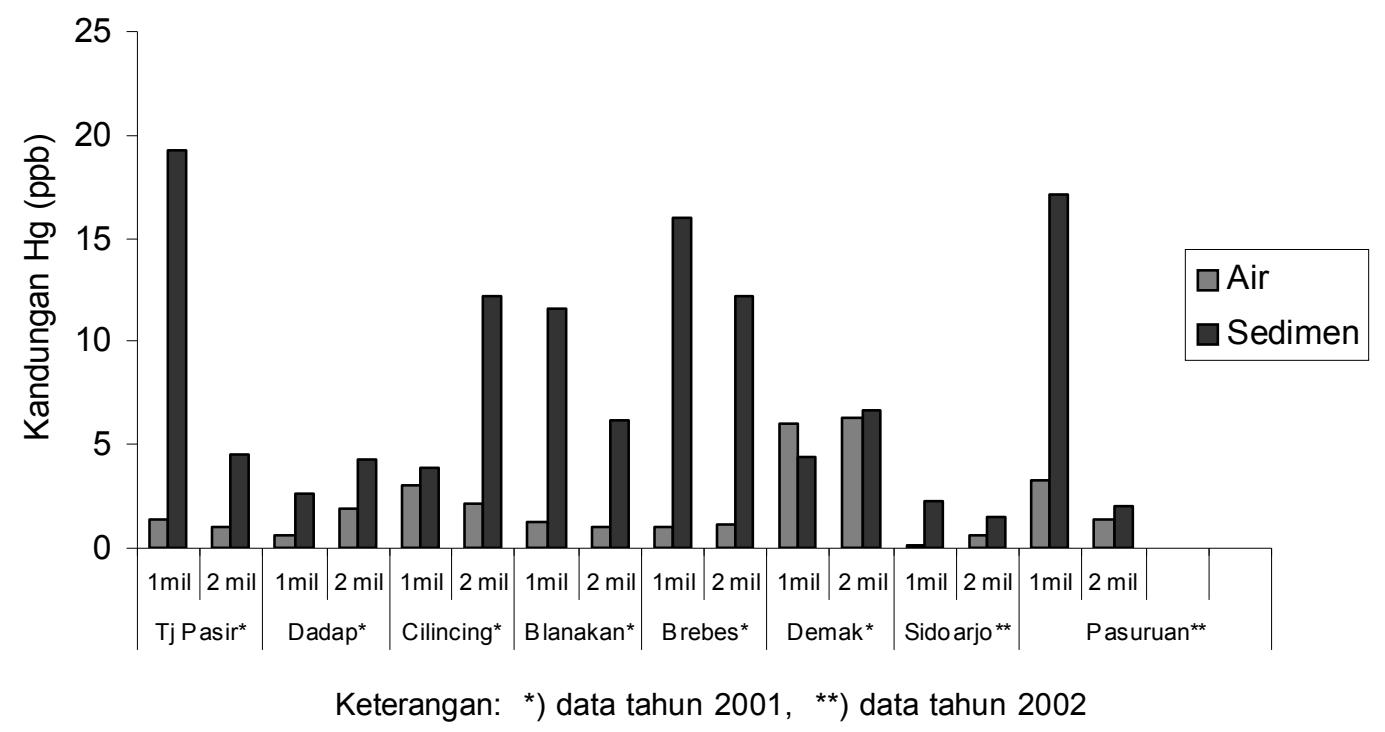

Gambar 2. Kandungan merkuri air laut dan sedimen di Perairan Jawa pada tahun 2001dan 2002.

Tabel 2. Kandungan logam berat kerang darah di Perairan Jawa tahun 2001 dan 2002

\begin{tabular}{lcrrr}
\hline \multirow{2}{*}{ Lokasi } & \multicolumn{4}{c}{ Kandungan logam berat (ppb) } \\
\cline { 2 - 5 } & $\mathbf{H g}$ & \multicolumn{1}{c}{$\mathbf{C d}$} & \multicolumn{1}{c}{$\mathbf{P b}$} & \multicolumn{1}{c}{$\mathbf{C u}$} \\
\hline Tanjung Pasir * & 9,93 & 12,26 & 65,00 & 12,86 \\
Dadap * & 8,54 & 7,21 & 53,45 & 47,45 \\
Cilincing * $^{*}$ & 9,06 & 0,85 & 34,00 & 12,70 \\
Blanakan * & 6,16 & 2,72 & 11,74 & 0,77 \\
Brebes * & 18,14 & $* * *$ & ${ }^{* * *}$ & ${ }^{* * *}$ \\
Demak * & 17,63 & ${ }^{* * *}$ & 46,78 & ${ }_{* * *}$ \\
Sidoarjo ** & 11,33 & 0,03 & 2,78 & 0,47 \\
Pasuruan ** & 16,48 & 0,06 & 0,08 & 0,15 \\
\hline
\end{tabular}

Keterangan: ${ }^{*}$ ) data tahun $2001,{ }^{* *}$ ) data tahun $2002,{ }^{* * *}$ ) Tidak terdeteksi

Kandungan merkuri di Kalimantan dan Sulawesi seperti terlihat pada Gambar 3 telah berada di atas ambang batas aman. Kandungan merkuri yang terdapat dalam sedimen juga sudah cukup tinggi. Menurut Murtini \& Peranginangin (2006), tingginya kandungan merkuri air laut di Perairan Banjarmasin kemungkinan disebabkan oleh penambangan emas yang dibuang melalui Sungai Barito. Di daerah Kalimantan Tengah terdapat ribuan penambang emas yang menggunakan merkuri untuk mengikat emas. Prosesnya dilakukan di atas rakit dan limbahnya langsung dibuang ke sungai yang akhirnya masuk ke perairan laut.
Kandungan logam berat pada kekerangan yang hidup di perairan Banjarmasin, Balikpapan, Pontianak, dan Makassar dapat dilihat pada Tabel 3. Pada Tabel tersebut terlihat residu logam berat yang terdapat dalam kekerangan masih di bawah ambang batas yang diijinkan oleh Ditjen POM (1989).

\section{d) Kondisi Perairan Muara di Kalimantan}

Kondisi perairan muara di Kalimantan diwakili oleh Muara Sungai Kahayan dan Muara Sungai Barito. Terlihat pada Tabel 4 kandungan logam berat air Muara Sungai Kahayan telah berada di atas ambang batas aman untuk perikanan. Ambang batas kandungan 


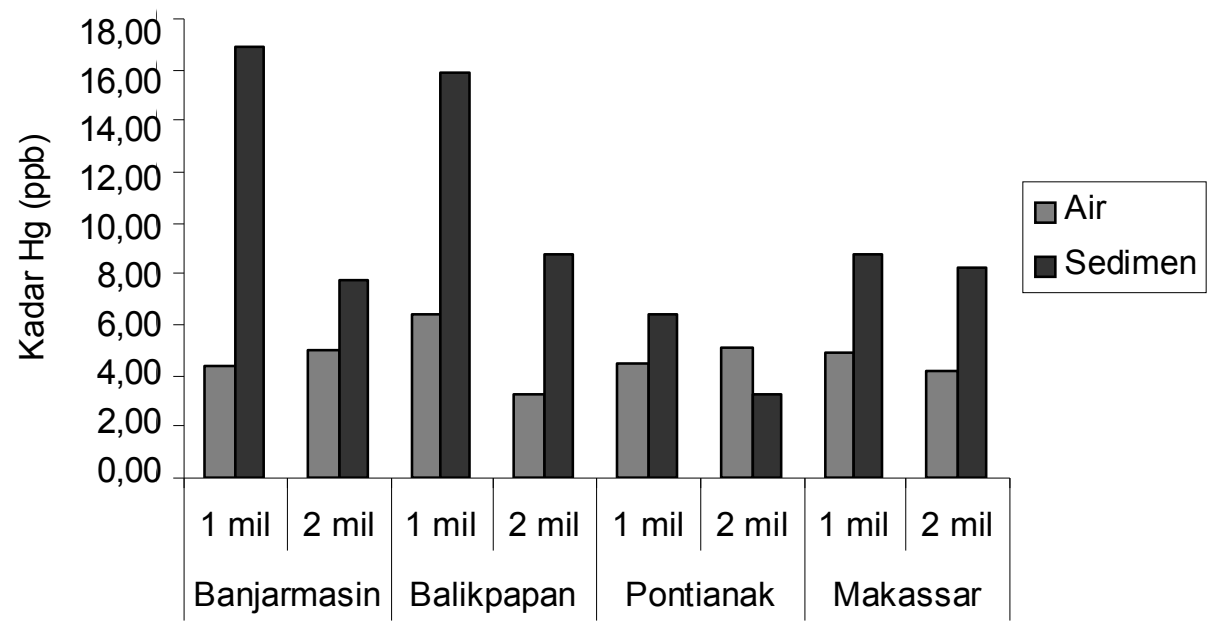

Gambar 3. Kandungan merkuri di Perairan Kalimantan dan Sulawesi tahun 2003.

Tabel 3. Kandungan logam berat pada kekerangan di Perairan Banjarmasin, Balikpapan, Pontianak, dan Makassar pada tahun 2003

\begin{tabular}{|c|c|c|c|c|c|c|}
\hline \multirow{2}{*}{ Loka si } & \multirow{2}{*}{ Bulan } & \multirow{2}{*}{ Jenis kerang } & \multicolumn{4}{|c|}{ Kandungan logam (ppb) } \\
\hline & & & $\mathrm{Hg}$ & Cd & $\mathbf{P b}$ & $\mathrm{Cu}$ \\
\hline Banjarmasin & Juni & Kepah & 2,16 & 0,22 & 0,14 & 0,46 \\
\hline \multirow[t]{4}{*}{ Balikpapan } & Juni & Kerang darah & 0,39 & 0,15 & 0,22 & 0,65 \\
\hline & Agustus & Kerang darah & 0,06 & 0,16 & 0,21 & 0,60 \\
\hline & Oktober & Kerang darah & 0,83 & 0,32 & 0,39 & 0,56 \\
\hline & & Kepah & 0,46 & 0,23 & 0,53 & 0,65 \\
\hline \multirow[t]{2}{*}{ Pontianak } & Juni & Kerang darah & 1,34 & 0,13 & 0,42 & 0,60 \\
\hline & Oktober & Kerang darah & 2,86 & 0,18 & 0,42 & 0,85 \\
\hline \multirow[t]{2}{*}{ Makassar } & Juni & Kepah & 1,74 & 0,14 & 0,33 & 0,08 \\
\hline & Oktober & Kepah & 0,29 & 0,14 & 0,33 & 0,09 \\
\hline
\end{tabular}

logam berat dalam perairan yang ditentukan bagi usaha perikanan adalah $\mathrm{Hg}(2 \mathrm{ppb}), \mathrm{Pb}(30 \mathrm{ppb}), \mathrm{Cu}$ (20 ppb), dan Cd (10 ppb) (Anon., 1990). Kandungan merkuri air Muara Sungai Kahayan lebih tinggi dibanding kandungan merkuri di Muara Sungai Barito. Hal ini diduga karena sepanjang sungai Kahayan lebih banyak industri rumah tangga di bidang amalgamasi emas. Proses amalgamasi menggunakan merkuri sebagai bahan bakunya. Limbah proses amalgamasi tersebut langsung dibuang ke Sungai Kahayan. Kandungan logam timbal di Muara Sungai Kahayan juga sudah tinggi walaupun belum melewati ambang batas tetapi harus sudah mendapat perhatian yang serius. Transportasi utama yang digunakan di sepanjang Sungai Kahayan dan Sungai Barito adalah kapal motor. Buangan gas dari kapal motor tersebut mengandung tetraethyl lead (TEL), sehingga mengakibatkan sungai tercemar oleh logam $\mathrm{Pb}$. Kandungan logam Cu baik di Muara Sungai Kahayan dan Sungai Barito sudah jauh di atas ambang batas. Menurut Priyanto \& Murtini (2006), tembaga digunakan sebagai campuran dan pengawet pada industri galangan kapal yang banyak terdapat di sepanjang Sungai Kahayan dan Sungai Barito. Selain itu, pencemaran ini kemungkinan juga disebabkan oleh pembuangan limbah industri perkayuan yang ada di hulu Sungai Kahayan (Murtini et al., 2005b). 
Pada Tabel 4 terlihat bahwa pada tahun 2005 kandungan $\mathrm{Hg}, \mathrm{Cd}, \mathrm{Pb}$, dan $\mathrm{Cu}$ pada sedimen sudah sangat tinggi, terutama kandungan tembaga sudah di atas $1.000 \mathrm{ppb}$. Menurut Amin (2001) tingginya kandungan tembaga pada sedimen berkaitan dengan mobilitas tembaga yang merupakan unsur esensial bagi tumbuhan. Pada Tabel 5 disajikan kandungan logam berat pada beberapa jenis produk perikanan yang berasal dari Muara Sungai Kahayan dan Muara Sungai Barito pada tahun 2005. Kandungan logam berat pada beberapa produk sudah cukup tinggi walaupun masih di bawah ambang batas yang diijinkan. Waktu penangkapan juga sangat mempengaruhi konsentrasi logam yang terdapat

Tabel 4. Kandungan logam berat di Perairan Muara Sungai Kahayan dan Muara Sungai Barito pada tahun 2005

\begin{tabular}{|c|c|c|c|c|c|}
\hline \multirow{2}{*}{ Lokasi } & & \multicolumn{4}{|c|}{ Kandungan logam (ppb) } \\
\hline & & $\mathrm{Hg}$ & Cd & $\mathbf{P b}$ & $\mathrm{Cu}$ \\
\hline \multirow[t]{2}{*}{ Muara Sungai Kahayan } & Air & 2,20 & 30,47 & 21,57 & 903,50 \\
\hline & Sedimen & 7,41 & 69,87 & 46,53 & $1.567,00$ \\
\hline \multirow[t]{2}{*}{ Muara Sungai Barito } & Air & 0,97 & 35,67 & 8,27 & 453,30 \\
\hline & Sedimen & 21,46 & 73,90 & 90,94 & $1.620,17$ \\
\hline
\end{tabular}

Tabel 5. Kandungan logam berat beberapa produk perikanan di Muara Sungai Kahayan dan Muara Sungai Barito pada tahun 2005

\begin{tabular}{|c|c|c|c|c|c|}
\hline \multirow{2}{*}{ Lokasi } & \multirow{2}{*}{ Jenis } & \multicolumn{4}{|c|}{ Kandungan logam (ppb) } \\
\hline & & $\mathrm{Hg}$ & Cd & $\mathbf{P b}$ & $\mathrm{Cu}$ \\
\hline \multirow[t]{9}{*}{ Muara Sungai Kahayan } & Utik asin & 46,74 & 102,27 & 10,79 & 54,54 \\
\hline & Sembilang asin & 147,93 & 112,05 & 15,83 & 55,30 \\
\hline & Gulamah asin & 120,11 & 129,62 & 37,87 & 47,81 \\
\hline & Bulu-bulu & 164,33 & 33,30 & 39,55 & 98,20 \\
\hline & Pisang-pisang & 245,56 & 18,87 & 45,23 & 116,50 \\
\hline & Kiper & 239,75 & 24,61 & 30,40 & 237,60 \\
\hline & Udang putih & 104,95 & 51,72 & 38,27 & 1232 \\
\hline & Udang windu & 3,92 & 14,86 & 11,45 & 56,25 \\
\hline & Kepiting & 3,35 & 83,67 & 1,86 & 491,75 \\
\hline \multirow[t]{9}{*}{ Muara Sungai Barito } & Utik asin & 10,62 & 8,50 & 10,76 & 135 \\
\hline & Layang & 4,97 & 69,67 & 23,90 & 51,55 \\
\hline & Selangat & 3,51 & 33,30 & 19,30 & 13,27 \\
\hline & Biawan & 3,25 & 13,95 & 12,07 & 2,64 \\
\hline & Sepat & 3,41 & 7,76 & 40,80 & 128,65 \\
\hline & Patin & 3,84 & 11,95 & 8,95 & 4,05 \\
\hline & Bandeng & 19,24 & 9,36 & 6,20 & 7,36 \\
\hline & Sepat asin & 1,72 & 29,27 & 0,42 & 29,59 \\
\hline & Puyau asin & 0,63 & 2,64 & 2,07 & 17,09 \\
\hline
\end{tabular}


Tabel 6. Kandungan logam berat pada air dari Waduk Saguling

\begin{tabular}{llrrrr}
\hline \multirow{2}{*}{ Lokasi } & \multirow{2}{*}{ Jenis sampel } & \multicolumn{4}{c}{ Kandungan logam $(\mathbf{p p b})$} \\
\cline { 3 - 6 } & & $\mathbf{H g}$ & \multicolumn{1}{c}{$\mathbf{C d}$} & \multicolumn{1}{c}{$\mathbf{P b}$} & \multicolumn{1}{c}{$\mathbf{C u}$} \\
\hline Jatiluhur & Air & 0,27 & 575,58 & 0,08 & 886,67 \\
& Sedimen & 65,00 & $27.602,69$ & 287,20 & 592,29 \\
\multirow{2}{*}{ Cirata } & Air & 4,78 & 8,81 & 0,09 & 5,25 \\
& Sedimen & 197,39 & 321,73 & 205,82 & 669,09 \\
\multirow{2}{*}{ Saguling } & Air & 1,10 & 10,63 & 371,19 & $2.871,00$ \\
& Sedimen & 114,34 & 53,10 & 244,00 & 663,00 \\
\hline
\end{tabular}

dalam daging biota tersebut. Menurut Priyanto \& Murtini (2006), ikan yang ditangkap pada bulan April mengandung logam yang lebih tinggi dibanding ikan yang ditangkap pada bulan September. Hal ini dikarenakan pada bulan September perairan sedang surut sehingga logam berat yang terkonsentrasi dalam air akan diabsorbsi lebih banyak oleh ikan. Menurut Ansari et al. (2004), tingkat konsentrasi logam berat pada organisme air seringkali sebanding dengan tingkat konsentrasi logam berat pada perairannya. Secara umum kandungan logam berat pada ikan masih berada di bawah ambang batas, tetapi untuk kandungan $\mathrm{Hg}$ terdapat beberapa jenis ikan yang harus mendapat perhatian karena telah berada di atas $100 \mathrm{ppb}$, mengingat logam berat bersifat akumulatif di dalam tubuh.

\section{e) Kondisi Perairan Waduk di Jawa Barat}

Ekosistem waduk yang berada di Jawa Barat diwakili oleh Waduk Jatiluhur, Waduk Cirata, dan Waduk Saguling. Ketiga waduk ini merupakan waduk yang terbesar di Jawa Barat. Kandungan logam berat pada air Waduk Jatiluhur, Waduk Cirata, dan Waduk Saguling disajikan pada Tabel 6. Kandungan logam $\mathrm{Hg}$ pada air Waduk Cirata telah berada di atas ambang batas aman untuk perikanan ( $2 \mathrm{ppb}$ ). Waduk Jatiluhur telah tercemar oleh logam $\mathrm{Cd}$ dan $\mathrm{Cu}$, sedangkan Waduk Saguling bukan hanya tercemar oleh logam Cd, dan Cu tetapi juga telah tercemar oleh logam $\mathrm{Pb}$. Kandungan logam berat sedimen pada ketiga waduk tersebut juga sudah sangat tinggi. Ketiga waduk ini digunakan untuk pembangkit tenaga listrik. Limbah dari kegiatan pembangkit tenaga listrik tersebut mencemari lingkungan perairan di ketiga waduk tersebut. Kondisi tanah di lingkungan Waduk Jatiluhur juga turut menyumbang tingginya kandungan Cd pada sedimennya.

Kandungan logam berat pada beberapa jenis ikan yang ditangkap di Waduk Jatiluhur, Waduk Cirata, dan
Waduk Saguling pada tahun 2005 disajikan pada Tabel 7. Terlihat bahwa kandungan logam berat yang terdapat dalam ikan masih berada di bawah ambang batas aman. Kandungan logam berat dalam daging ikan tersebut masih di bawah ambang batas, pada beberapa jenis ikan harus mendapat perhatian karena kandungannya sudah cukup tinggi.

\section{PENUTUP}

Kondisi perairan laut di Sumatera yang diwakili oleh Perairan Mentok, Bagan Siapi-api, Tanjung Jabung Timur, dan Tanjung Balai masih aman. Untuk usaha perikanan kandungan $\mathrm{Hg}$ pada perairan tersebut pada tahun 2002 masih di bawah ambang batas aman untuk perikanan, namun demikian untuk perairan Tanjung Balai harus sudah mendapat perhatian karena kandungan merkuri air lautnya sudah mendekati ambang batas aman untuk perikanan, yaitu $2 \mathrm{ppb}$. Kerang darah yang hidup di Perairan Sumatera masih aman untuk dikonsumsi.

Kondisi beberapa perairan di Pulau Jawa dan Bali harus mendapat perhatian yang serius. Hasil monitoring pada tahun 2001 dan 2002 menunjukkan bahwa kandungan $\mathrm{Hg}$ air laut Perairan Dadap, Cilincing, Demak, dan Pasuruan telah melewati ambang batas, yaitu di atas $2 \mathrm{ppb}$. Perairan Tanjung Pasir, Blanakan, Sidoarjo, dan Gondol masih berada di bawah ambang batas aman. Kekerangan yang hidup di Perairan Jawa masih berada di bawah ambang batas tetapi ada beberapa yang harus mendapat perhatian serius karena kandungan $\mathrm{Hg}$ sudah tinggi yaitu di atas $100 \mathrm{ppb}$, mengingat logam berat dapat terakumulasi dalam tubuh manusia yang mengkonsumsinya.

Perairan laut di Kalimantan dan Sulawesi yang diwakili oleh Banjarmasin, Balikpapan, Pontianak, dan Makassar pada tahun 2003 harus mendapat perhatian 
Tabel 7. Kandungan logam berat beberapa jenis ikan dari Waduk Jatiluhur, Waduk Cirata, dan Waduk Saguling pada tahun 2005

\begin{tabular}{|c|c|c|c|c|c|}
\hline \multirow{2}{*}{ Lokasi } & \multirow{2}{*}{ Jenis ikan } & \multicolumn{4}{|c|}{ Kandungan logam (ppb) } \\
\hline & & $\mathrm{Hg}$ & Cd & $\mathbf{P b}$ & $\mathrm{Cu}$ \\
\hline \multirow[t]{10}{*}{ Waduk Jatiluhur } & Nila KJA & 2,58 & 10,19 & 11,56 & 83,33 \\
\hline & Nila Liar & 4,51 & 3,36 & 15,42 & 35,02 \\
\hline & Patin KJA & 17,76 & 4,06 & 9,98 & 408,32 \\
\hline & Patin liar & 5,29 & 6,55 & 17,42 & 168,80 \\
\hline & Mas KJA & 4,49 & 35,20 & 3,46 & 83,17 \\
\hline & Mas liar & 27,29 & 5,37 & 13,80 & 72,64 \\
\hline & Gabus liar & 0,81 & 40,90 & 17,54 & 2,10 \\
\hline & Oscar & 7,08 & - & 38,25 & 1,72 \\
\hline & Manyung liar & 4,83 & 31,19 & 19,79 & 16,41 \\
\hline & Betutu liar & 7,85 & 55,12 & 2,35 & 3,01 \\
\hline \multirow[t]{5}{*}{ Waduk Cirata } & Nila KJA & 15,00 & 7,44 & 24,32 & 50,87 \\
\hline & Nila Liar & 0,29 & 27,55 & 8,46 & $1.663,00$ \\
\hline & Patin KJA & 0,64 & 34,22 & 14,63 & $2.367,00$ \\
\hline & Patin liar & 8,83 & 10,48 & 22,23 & 328,35 \\
\hline & Mas KJA & 95,60 & 5,82 & 7,77 & 66,60 \\
\hline \multirow[t]{5}{*}{ Waduk Saguling } & Nila KJA & 17,00 & 5,56 & 23,22 & 119,02 \\
\hline & Nila liar & 10,31 & 5,17 & 7,54 & 102,43 \\
\hline & Patin KJA & 10,04 & 1,89 & 11,45 & 38,14 \\
\hline & Mas KJA & 1,77 & 2,10 & 1,93 & 64,20 \\
\hline & Gabus KJA & 6,68 & 2,32 & 1,60 & 34,50 \\
\hline
\end{tabular}

yang serius karena kandungan $\mathrm{Hg}$ telah melewati ambang batas ( $2 \mathrm{ppb}$ ). Namun kekerangan yang hidup di perairan tersebut masih aman untuk dikonsumsi.

Kandungan logam berat $\mathrm{Cu}$ dan Cd air Muara Sungai Kahayan dan Barito pada tahun 2005 sudah melewati ambang batas $(\mathrm{Cu}=20 \mathrm{ppb}$ dan $\mathrm{Cd}=10$ $\mathrm{ppb}$ ), sedangkan kandungan $\mathrm{Hg}$ masih berada di bawah ambang batas. Secara umum ikan yang hidup di perairan tersebut masih aman untuk dikonsumsi walaupun pada beberapa jenis ikan harus mendapat perhatian karena kandungan $\mathrm{Hg}(>100 \mathrm{ppb})$ dan $\mathrm{Cu}$ (>1000 ppb) sudah cukup tinggi.

Air Waduk Saguling telah tercemar oleh logam $\mathrm{Pb}, \mathrm{Cd}$, dan $\mathrm{Cu}$, sementara air Waduk Cirata tercemar oleh logam Hg dan Waduk Jatiluhur tercemar logam
Cu dan Cd. Meskipun demikian, ikan yang hidup di ketiga waduk tersebut masih aman untuk dikonsumsi karena kandungan logam beratnya masih berada di bawah ambang batas.

\section{DAFTAR PUSTAKA}

Acker, L.A., McMAhan, J.R., and Gawel, J.E. 2005. The effect of heavy metal pollution in aquatic environment on methallothionein production in Mytilus sp. Proceeding of the 2005 Puget Sound Georgia Basin Research Conference. 7 pp.

Amin, B. 2001. Akumulasi dan Distribusi Logam Berat $\mathrm{Pb}$ dan $\mathrm{Cu}$ pada Mangrove (Avicennia marina) di Perairan Pantai Dumai, Riau. Laboratorium Kimia Laut. Faperika. Universitas Riau. 7 pp.

Anonim. 1989. Keputusan Ditjen Pengawas Obat dan Makanan No. 13725/B/SK.VII/1989. 
Anonim. 1990. Peraturan Pemerintah RI No. 20 Tahun 1990 Tanggal 5 Juni 1990 tentang Pengendalian Pencemaran Air.

Anonim. 2007. Posisi terkini perdagangan hasil perikanan Indonesia. http:// www. indonesia. go. id. 4 pp. Diakses tanggal 28 September 2007.

Anonymous. 1998. Compendium of Fish and Fishery Product. Processes, Hazards and Control First ed. Chemical Hazards and Controls. Raleigh, NC, USA : National Seafood HACCP Alliance for Training and Education. P.23.2.

Anonymous. 2005. Mercury migration series. www.ban.org/Ban-Hg-Wg. Diakses tanggal 18 Juni 2007.

Anonymous. 2006. Chemical properties of copper health effect of copper-environmental effect of copper. Lenntench Water Treatment and Air Purification. 5 pp.

Ansari, T.M., Marr, I.L., and Tarig, N. 2004. Heavy metals in marine pollutan perspective a mini review. J. Applied Sci. 4(1): 1-20.

Fajri, N.E. 2001. Analisis Kandungan Logam Berat Hg, $\mathrm{Cd}$ dan $\mathrm{Pb}$ dalam Air Laut, Sedimen dan Tiram (Carassostrea cucullatta) di Perairan Pesisir Kecamatan Pedes, Kabupaten Karawang, Jawa Barat. Thesis. Pasca Sarjana. IPB. Bogor. 62 pp.

Irianto, H.E. dan Poernomo, A. 2000. Keamanan konsumsi produk perikanan. Warta Penelitian Perikanan. 6(2): 5-7.

Mulyono, D. 2000. Teluk Jakarta dan Kualitas Hasil Perikanan. Lingkungan dan Pembangunan. 20 (2): 117-123.

Murtini, J.T., Ariyani, F., Wahyuni, I.S., Hak, N., Suherman, M., Dolaria, N., dan Nurwiyanto. 2001. Penelitian inventarisasi dan identifikasi pencemaran logam berat pada perairan dan ikan. Laporan Teknis. Pusat Riset Pengolahan Produk dan Bioteknologi Kelautan da Perikanan. Jakarta. $42 \mathrm{pp}$.

Murtini, J.T., Yennie, Y., Hikmayani, Y., Suherman, M., Sabarudin., dan Dolaria, N. 2002. Penelitian inventarisasi dan identifikasi pencemaran logam berat pada perairan dan ikan. Laporan Teknis. Pusat Riset Pengolahan Produk dan Sosial Ekonomi Kelautan dan Perikanan. Jakarta. 80 pp.

Murtini, J.T., Abdulsari., Peranginangin, R., Aji, N., Yennie, Y., Januar, H. I., Sabarudin., Dolaria, N., dan Carkipan. 2003a. Riset biotoksin dan logam berat pada produk perikanan untuk keamanan pangan. Laporan Teknis. Pusat Riset Pengolahan Produk dan Sosial Ekonomi Kelautan dan Perikanan. Jakarta. 83 pp.

Murtini, J.T., Yennie, Y., dan Peranginangin, R. 2003b. Kandungan logam berat pada kerang darah (Anadara granosa), air laut dan sedimen di perairan
Tanjung Balai dan Bagan Siapi-api. J. Penel. Perik. Indonesia 9 (5) : 77-84

Murtini, J.T., Yennie, Y., dan Ariyani, F. 2003c. Penelitian pencemaran logam berat di Selat Madura dan Selat Bali. Prosiding Seminar Nasional Perikanan Indonesia 2003. Sekolah Tinggi Perikanan. Jakarta. 1 : p. 83-93.

Murtini, J.T. dan Ariyani, F. 2005a. Kandungan logam berat kerang darah (Anadara granosa) dan kualitas perairan di Tanjung Pasir, Jawa Barat. J. Penel. Perik. Indonesia. 11 (8) : 39-45.

Murtini, J.T., Heruwati, E.S., Dwiyitno., dan Aji, N. 2005b. Riset identifikasi residu logam berat dan pestisida pada produk perikanan. Laporan Teknis. Pusat Riset Pengolahan Produk dan Sosial Ekonomi Kelautan dan Perikanan. Jakarta. 93 pp.

Murtini, J.T. dan Peranginangin, R. 2006. Kandungan logam berat pada kerang kepah (Meritrix meritrix) dan air laut di Perairan Banjarmasin. J. Perik. 8 (2) : 177-184.

Priyanto, N. dan Murtini, J.T. 2006. Kandungan logam berat pada ikan yang ditangkap dari Muara Sungai Kahayan, Kalimantan Tengah. J. P. B. Perikanan. 1 (2) : 135-141.

Raharjo. 1999. Detention of food exported from Indonesia to USA by FDA in 1998. Indonesia Food and Nutrition. Gadjah Mada University. Yogyakarta. Indonesia. p. 59-63.

Rahmansyah. 1997. Akumulasi logam berat (pb) dalam tubuh udang windu (Penaeus monodon) pada kondisi salinitas dan individu yang berbeda. Laporan Hasil Penelitian Perikanan Pantai. Balai Penelitian Perikanan Pantai, Maros.

Rochyatun, E. 1997. Pemantauan Kadar Logam Berat (PB, Cd dan Cr) dalam Sedimen di Muara Sungai Dadap (Teluk Jakarta), dalam Inventarisasi dan Evaluasi Potensi Laut Pesisir II. Puslitbang Oseanologi. LIPI. Jakarta. p. 25-30.

Tewari, A., Joshi, H.V., Raghunathan, C., Kumar, V.G.S., and Khambhaty, Y. 2001. Effect of heavy metal pollution on growth, carotenoid and bacterial flora in the gut of perna viridis (L.) in in situ condition. Current Science. 81 (7) : 819-828.

Wahyuni, I.S. dan Hartati, S.T. 1991. Penelitian kualitas perairan pantai barat teluk Jakarta. Prosiding Temu Karya IImiah Perikanan Rakyat. Buku II. Jakarta. $27 \mathrm{pp}$.

Yennie, Y. dan Murtini, J.T. 2005. Kandungan logam berat air laut, sedimen dan daging kerang darah (Anadara granosa) di perairan mentok dan tanjung jabung timur. J. IImu-IImu Perairan dan Perik. Indonesia. Dep. MSP, FPIK, IPB. 12 (1) : 27-32. 